\title{
The arbuscular mycorrhizal fungus Glomus mosseae gives contradictory effects on phosphorus and arsenic acquisition by Medicago sativa Linn
}

\author{
Baodong Chen ${ }^{\text {a }}$, Xueyi Xiao ${ }^{\text {a }}$, Yong-Guan Zhu ${ }^{\text {a,* }}$, F. Andrew Smith ${ }^{\text {b }}$, \\ Z. Miao Xie ${ }^{c}$, Sally E. Smith ${ }^{b}$ \\ ${ }^{a}$ Department of Soil Environmental Sciences/State Key Laboratory of Environmental Chemistry and Ecotoxicology, Research Center for \\ Eco-Environmental Sciences, Chinese Academy of Sciences, Beijing 100085, P.R. China \\ ${ }^{\mathrm{b}}$ Soil and Land Systems, School of Earth and Environmental Sciences, Waite Campus, The University of Adelaide, South Australia 5005, Australia \\ ${ }^{\mathrm{c}}$ Department of Environmental Science and Engineering, Hangzhou Dianzi University, Hangzhou 310018, China
}

Received 23 January 2006; received in revised form 4 July 2006; accepted 4 July 2006

Available online 6 December 2006

\begin{abstract}
Mycorrhizal fungi may play an important role in protecting plants against arsenic (As) contamination. However, little is known about the direct and indirect involvement of arbuscular mycorrhizal fungi (AMF) in detoxification mechanisms. A compartmented pot cultivation system ('cross-pots') is used here to investigate the roles of AMF Glomus mosseae in plant phosphorus (P) and As acquisition by Medicago sativa, and $\mathrm{P}$-As interactions. The results indicate that fungal colonization dramatically increased plant dry weight by a factor of around 6, and also substantially increased both plant $\mathrm{P}$ and As contents (i.e. total uptake). Irrespective of $\mathrm{P}$ and As addition levels, AM plants had shoot and root P concentrations 2 fold higher, but As concentrations significantly lower, than corresponding uninoculated controls. The decreased shoot As concentrations were largely due to "dilution effects" that resulted from stimulated growth of AM plants and reduced As partitioning to shoots. The study provides further evidence for the protective effects of AMF on host plants against As contamination, and have uncovered key aspects of underlying mechanisms. The possible application of AMF in remediation practices is discussed.
\end{abstract}

(C) 2006 Elsevier B.V. All rights reserved.

Keywords: Alfalfa; Arbuscular mycorrhiza; Phosphorus; Arsenic

\section{Introduction}

Arsenic (As) is ubiquitous in the environment, and is highly toxic to most biological systems. Elevated As concentrations in soils have been found in areas impacted by mining and smelting industries, and by coal burning throughout the world (Nriagu, 1994). The application of

\footnotetext{
* Corresponding author. Tel.: +86 1062936940 ; fax: +86 1062923563 .

E-mail address: ygzhu@rcees.ac.en (Y.-G. Zhu).
}

As-containing agrochemicals to domestic and agricultural land has also caused accumulation of As in soils (Woolson et al., 1971; Murphy and Aucott, 1998). Plant uptake of As from contaminated soils represents a significant pathway of human exposure. Understanding plant uptake metabolism of As is thus critical for estimating the risks associated with soil As contamination and for formulating countermeasures to minimize the accumulation of As in plants consumed directly by humans, farm animals or wildlife (Meharg and Hartley-Whitaker, 2002). 
Arbuscular mycorrhizal fungi (AMF) can form symbiotic relationships with the vast majority of land plants, and are known to benefit the phosphorus (P) nutrition of host plants by increasing $\mathrm{P}$ acquisition (Smith and Read, 1997). The pathway includes 1) $\mathrm{P}$ uptake by extensive and highly branched extraradical hyphae, 2) translocation via hyphae towards plant roots, 3) release of Pi at the arbuscular interface and efficient transfer of Pi to root cells. Arsenate, the dominant As species under aerobic conditions, is known to be an analogue of phosphate (Pi), and Pi can effectively inhibit plant uptake of arsenate (Meharg and Macnair, 1991, 1992). Due to the similarity between Pi and arsenate, understanding the role of AMF in plant uptake of arsenate is essential in predicting the biogeochemistry of As in the terrestrial environment.

In recent studies of the role of mycorrhizal fungi in adaptation of host plants to As-contaminated soils, Sharples et al. (2000a,b) reported that the key mechanism by which the ericoid mycorrhizal fungus Hymenoscyphus ericae could improve resistance of Calluna vulgaris to As toxicity was through As exclusion. In a similar manner to bacteria and yeasts (Rosen, 1999), the fungus achieves arsenate resistance by reducing arsenate to arsenite, and pumping arsenite out of the fungal cells (Sharples et al., 2000a,b). In a more recent study on arsenate resistance of Holcus lanatus conferred by AMF, Gonzalez-Chavez et al. (2002) found that regardless of their arsenate resistance, the AMF strains tested could all reduce arsenate influx into $H$. lanatus plant roots. Decreased As concentration but increased As content in the As hyperaccumulating fern Pteris vittata due to colonization by AMF was observed by Liu et al. (2005). There are two possible reasons for AMF-mediated arsenate resistance: 1) AMF colonization may down-regulate the high-affinity Pi transport system in plant roots that also absorbs arsenate; 2) AMF may increase the efflux of As (as arsenite) from mycorrhizal roots. However, overall information on AMF-As interactions is very limited and more studies are needed, particularly to reveal the underlying mechanisms of protective effects of AMF on host plants under As contamination, and to look further into the mycorrhiza-mediated $\mathrm{P}-\mathrm{As}$ interactions.

By using a compartmented ('cross-pot') cultivation system based on the design of Pearson and Jakobsen (1993), the present study aimed to 1) reveal direct and indirect involvement of AMF in As uptake by plants, 2) compare $\mathrm{P}$ and As uptake via the mycorrhizal pathway and their possible interactions, 3) elucidate the underlying mechanisms of protective effects of AMF on host plants, and 4) discuss the possible use of AMF in remediation of As-contaminated soil environments.

\section{Materials and methods}

\subsection{Host plants and AM fungus}

Seeds of Medicago sativa Linn. cv. Chuangxin were pre-germinated on moist filter paper for about $36 \mathrm{~h}$ and were selected for uniformity before sowing. Plants were grown without or with inoculum of the AM fungus Glomus mosseae (Nicol. and Gerd.) Gerdemann and Trappe. The original inoculum was procured with the courtesy of Prof. Y.S. Wang of the Institute of Plant Nutrition and Fertilizers (IPNF), Beijing Academy of Agronomy and Forestry with an inventory number Glm93 at the laboratory of the IPNF. Inoculum from pot cultures of sorghum plants was a mixture of spores, mycelium, sand and root fragments containing approximately 1000 spores per $100 \mathrm{~g}$.

\subsection{Cultivation system}

The compartmented cultivation system ('cross-pot') consists of a standing PVC tube $(5.7 \mathrm{~cm}$ diameter $\times 25 \mathrm{~cm}$ long) for plant growth (root and hyphae compartment, RHC) and two side-arms ( $4.2 \mathrm{~cm}$ diameter $\times 8 \mathrm{~cm}$ long) fixed tightly to the standing tube. The side-arms are separated from the RHC by $37 \mu \mathrm{m}$ nylon meshes that allow only hyphal penetration. In one side-arm, two phosphorus $\left(\mathrm{KH}_{2} \mathrm{PO}_{4} \mathrm{P}\right)$ addition levels (25 and $100 \mathrm{mg} \mathrm{P} \mathrm{kg}{ }^{-1}$ ) (hyphal compartment with $\mathrm{P}$ added, HCP), and in the opposite one, three arsenic $\left(\mathrm{Na}_{3} \mathrm{AsO}_{4} \cdot 12 \mathrm{H}_{2} \mathrm{O}^{-} \mathrm{As}\right)$ addition levels $\left(0,25\right.$ and $\left.100 \mathrm{mg} \mathrm{As} \mathrm{kg}{ }^{-1}\right)$ were arranged (hyphal compartment with As added, HCA) (Fig. 1).

\subsection{Growth medium}

A calcareous loamy soil was collected from the experimental station of the Institute of Genetics and Developmental Biology, the Chinese Academy of Sciences, Changping County, Beijing, China. The soil had a $\mathrm{pH}$ of 8.53 (1: 2.5 soil to water), extracs P content of $11.35 \mathrm{mg} \mathrm{kg}^{-1}$ (using the methods described by Olsen et al., 1954) and extractable As of $0.25 \mathrm{mg} \mathrm{kg}^{-1}$ (extracted by $0.5 \mathrm{~mol} \mathrm{~L}^{-1} \mathrm{NaHCO}_{3}$ ). The soil was passed through a $2 \mathrm{~mm}$ sieve and partially sterilized (10 kGy, $10 \mathrm{MeV}$ electron beam).

\subsection{Experimental procedure}

Each side-arm of the cross-pot was filled with $125 \mathrm{~g}$ sterilized loamy soil with $\mathrm{P}$ or As addition, then with $30 \mathrm{~g}$ soil without any amendments to establish a buffer layer and minimize possible movement of added $\mathrm{P}$ or As 


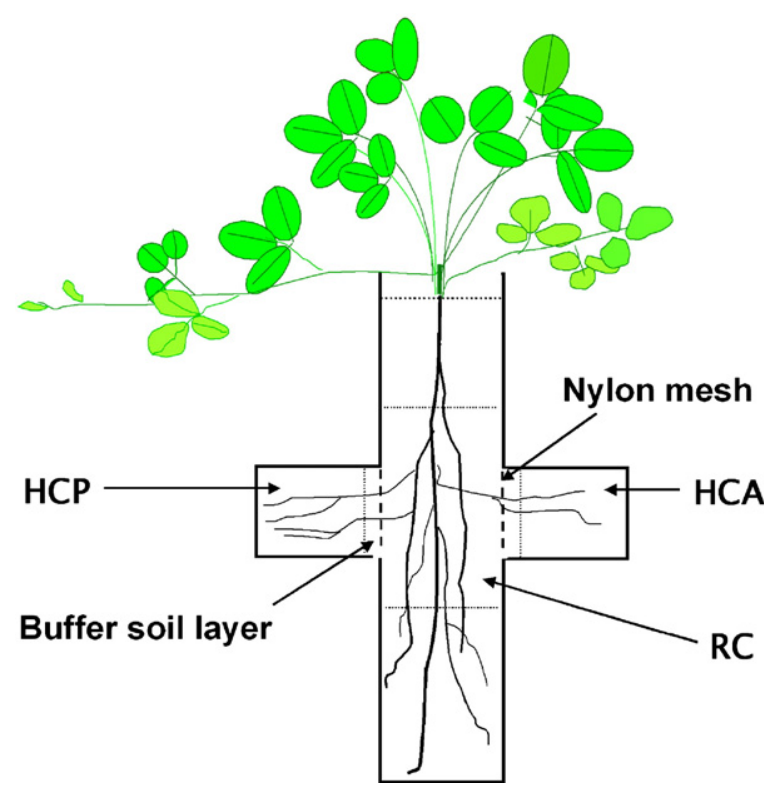

Fig. 1. Diagram of the compartmented cultivation system. Two hyphal compartments (HC) were separated from the central root compartment (RHC) by $37 \mu \mathrm{m}$ nylon net. M. sativa plants grown in RHC were either inoculated with $G$. mosseae $(+\mathrm{M})$ or kept uninoculated $(-\mathrm{M})$. HCP received 25 or $100 \mathrm{mg} \mathrm{P} \mathrm{kg}^{-1}$ and $\mathrm{HCA}$ received 0,25 or $100 \mathrm{mg} \mathrm{As}$ kgsuper $^{-1}$ soil.

from side-arms to the RHC. After installing the soil into side-arms, deionized water was carefully added to the soil to keep 55\% moisture holding capacity. The sidearm tubes were then sealed with $37 \mu \mathrm{m}$ nylon net and allowed to stand overnight.

A 1:1 (w/w) mixture of soil and sand (passed through a $2 \mathrm{~mm}$ sieve and sterilized; referred to as 'soil' below) that received basal nutrients excluding $\mathrm{P}$ (Pearson and Jakobsen, 1993) was filled into RHC to support plant growth. After fixing the side-arms to RHC, the latter were sealed at the base by plastic bags, filled firstly with $300 \mathrm{~g}$ soil, then with a mixture of 260 soil and $40 \mathrm{~g}$ inoculum for inoculated treatments, or the same amount of soil-sand mixture plus $10 \mathrm{ml}$ inoculum filtrate for uninoculated controls, and finally with $150 \mathrm{~g}$ soil. Both inoculated and uninoculated plants were in combination with two $\mathrm{P}$ addition levels and three As levels in the sidearms. The resulting 12 treatments had four replicates and the 48 pots were set up in a randomized block design. After the pot installation, deionized water was added to RHC to reach a moisture content of 55\% water holding capacity (WHC), and the amended soil was allowed to equilibrate for 1 week in a controlled environment glasshouse $\left(16 \mathrm{~h}-25^{\circ} \mathrm{C}\right.$ day and $8 \mathrm{~h}-18{ }^{\circ} \mathrm{C}$ night and natural light) where the experiment was conducted. Each pot was then sown with 10 pre-germinated seeds, and 1 week after emergence seedlings were thinned to four per pot. The plants grew for 8 weeks from 26 February to 21 April 2004. Deionized water was added as required to maintain moisture content at $55 \%$ of WHC by regular weighing. Nitrogen (as $\mathrm{NH}_{4} \mathrm{NO}_{3}$ ) was added to the RHC 35 days after sowing to provide a total of $90 \mathrm{mg} \mathrm{N}$ per pot.

\subsection{Harvest and chemical analysis}

At harvest, the side-arms were separated from RHC and the outer soil layer was discarded. The P- or Asamended soil cores from $\mathrm{HC}$, together with soil samples from $\mathrm{RHC}$ were air-dried, and soil $\mathrm{pH}$, hyphal length density and extractable P (RHC and HCP) or As (HCA) were determined. Plant shoots and roots from RHC were harvested separately. All plant samples were carefully washed with deionized water to remove adhering soil particles. Sub-samples of fresh roots were collected for the determination of AM colonization. Dry weights of shoots and roots were determined after oven-drying at $70{ }^{\circ} \mathrm{C}$ for $48 \mathrm{~h}$. Oven-dried sub-samples were milled and sub-samples were digested using a microwave accelerated reaction system (Mars5, CEM Corporation): a subsample of about $200 \mathrm{mg}$ was accurately weighed into a PTFE pressure vessel and $5 \mathrm{ml}$ of concentrated $\mathrm{HNO}_{3}$ added. The microwave digestion program settings were

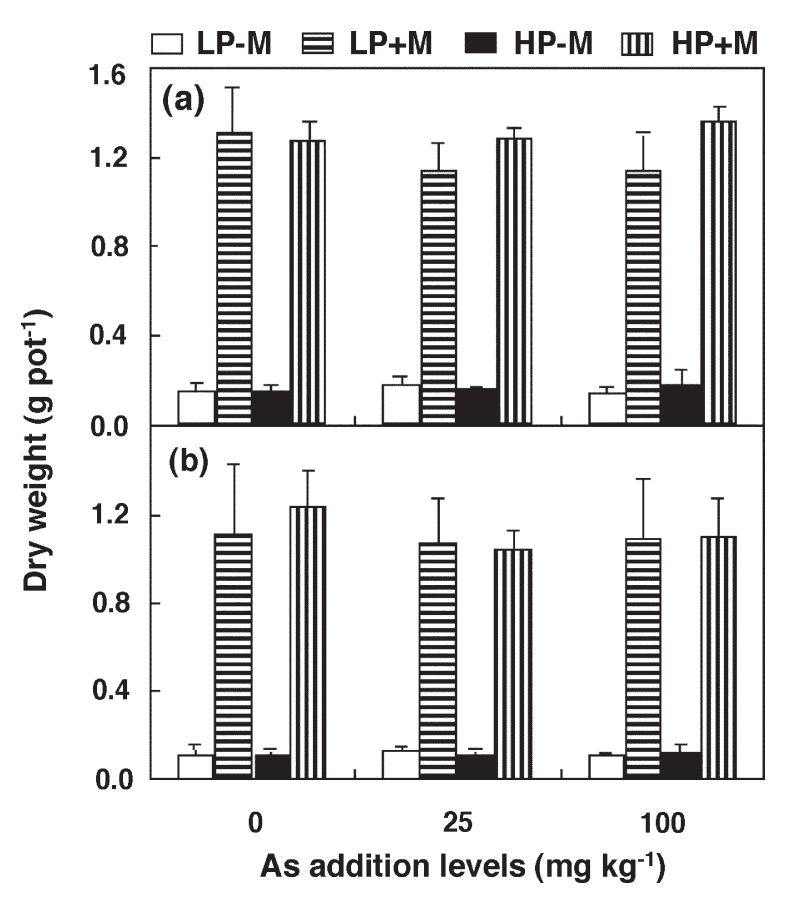

Fig. 2. Dry weight of shoots (a) and roots (b) of M. sativa. $-\mathrm{M}$ and $+\mathrm{M}$ represent uninoculated and inoculated treatments. LP and HP refer to 25 and $100 \mathrm{mg} \mathrm{P} \mathrm{kg}^{-1}$ in HCP respectively. 
Table 1

Colonization and hyphal length density of $M$. sativa colonized by $G$. mosseae as influenced by $\mathrm{P}$ and As addition treatments. (Data for uninoculated treatments not shown: root colonization was $0 \%$ and mean hyphal length densities were not more than $0.2 \mathrm{~m} \mathrm{~g}^{-1}$ )

\begin{tabular}{llllll}
\hline $\begin{array}{l}\text { P addition levels } \\
\text { in HCP }\left(\mathrm{mg} \mathrm{kg}^{-1}\right)\end{array}$ & $\begin{array}{l}\text { As } \\
\text { addition } \\
\text { levels } \\
\text { in HCA } \\
\left(\mathrm{mg} \mathrm{kg}^{-1}\right)\end{array}$ & $\begin{array}{l}\text { Root } \\
\text { colonization } \\
(\%)\end{array}$ & $\begin{array}{l}\text { Hyphal length } \\
\text { density }\left(\mathrm{m} \mathrm{g}^{-1}\right)\end{array}$ \\
\cline { 4 - 6 } & 0 & 85 & 7.8 & 2.2 & 2.0 \\
\hline 25 & 25 & 79 & 6.7 & 3.1 & 4.4 \\
& 100 & 82 & 4.8 & 4.9 & 3.7 \\
100 & 0 & 83 & 6.0 & 6.9 & 3.6 \\
& 25 & 87 & 5.8 & 7.2 & 4.1 \\
& 100 & 85 & 4.5 & 5.8 & 3.4 \\
Significance & & & & & HCA \\
Inoculation (I) & & $* * *$ & $* * *$ & $* * *$ & $* * *$ \\
Phosphorus (P) & & NS & NS & $* * *$ & NS \\
Arsenic (A) & & NS & $* *$ & NS & NS \\
I $\times$ P & & NS & NS & $* * *$ & NS \\
I $\times$ A & & NS & $* *$ & NS & NS \\
P $\times$ A & & NS & NS & NS & NS \\
I $\times$ P $\times$ A & & NS & NS & NS & NS \\
\hline
\end{tabular}

${ }^{\mathrm{a}}$ By analysis of variance; ***, $P<0.001 ; * *, P<0.01{ }^{*}, P<0.05$; NS, not significant.

as follows: power $1200 \mathrm{~W}$, temperature $160{ }^{\circ} \mathrm{C}$, pressure $350 \times 10^{5} \mathrm{~Pa}$ and holding time $15 \mathrm{~min}$. After cooling, the sample solution was transferred with deionized water and filtered into a $50 \mathrm{ml}$ plastic bottle. Sample As concentrations were determined using an atomic fluorescence spectrometer (Model AF-610A, Beijing Rayleigh Analytical Instrument Co., China) (Vilanó and Rubio, 2001) and $\mathrm{P}$ concentrations were analyzed using the phosphovanado-molybdate colorimetry method (Hanson, 1950) with a spectrophotometer (Model UV757CRT, Shanghai Scientific Instrument Co. Ltd, China).

Sub-samples of fresh roots were cleared in $10 \% \mathrm{KOH}$ and stained with Trypan blue by a modified procedure of Phillips and Hayman (1970), omitting phenol from solutions and $\mathrm{HCl}$ from the rinse. Percentage root colonization and root length were determined by the grid-line intersect method (Giovannetti and Mosse, 1980). External hyphae were extracted from soil samples using a modified membrane filter technique (Jakobsen et al., 1992). Duplicate $3 \mathrm{~g}$ soil samples were blended with $250 \mathrm{ml}$ water and hyphae in $5 \mathrm{ml}$ aliquots were collected on $37.5 \mathrm{~mm}$ membrane filters $(1.2 \mu \mathrm{m})$ and stained with Trypan blue. Hyphal length was recorded in 40 random fields of view per filter. The length of stained hyphae on the filters was determined by the grid-line intercept method at $\times 200$ magnification (Tennant, 1975).

Soil $\mathrm{pH}$ was measured with a potentiometer (Thermo Orion Model 868) at a 1:2.5 soil:water ratio. Because As is chemically similar to $\mathrm{P}$, the same chemical extractant has been employed to determine the available fractions

Table 2

$\mathrm{P}$ and As concentrations in M. sativa as influenced by colonized by G. mosseae and different $\mathrm{P}$ and As addition treatments

\begin{tabular}{|c|c|c|c|c|c|c|c|c|}
\hline $\begin{array}{l}\text { Inoculation } \\
\text { treatment }\end{array}$ & $\begin{array}{l}\mathrm{P} \text { addition levels } \\
\text { in } \mathrm{HCP} \\
\left(\mathrm{mg} \mathrm{kg}^{-1}\right)\end{array}$ & $\begin{array}{l}\text { As addition levels } \\
\text { in } \mathrm{HCA}\left(\mathrm{mg} \mathrm{kg}^{-1}\right)\end{array}$ & $\begin{array}{l}\text { Shoot } \mathrm{P} \\
\text { concentration } \\
\left(\mathrm{mg} \mathrm{g}^{-1}\right)\end{array}$ & $\begin{array}{l}\text { Root } \mathrm{P} \\
\text { concentration } \\
\left(\mathrm{mg} \mathrm{g}^{-1}\right)\end{array}$ & $\begin{array}{l}\text { Shoot As } \\
\text { concentration } \\
\left(\mathrm{mg} \mathrm{kg}^{-1}\right)\end{array}$ & $\begin{array}{l}\text { Root As } \\
\text { concentration } \\
\left(\mathrm{mg} \mathrm{kg}^{-1}\right)\end{array}$ & $\begin{array}{l}\mathrm{P} / \mathrm{As} \\
\text { ratio in } \\
\text { shoots }\end{array}$ & $\begin{array}{l}\mathrm{P} / \mathrm{As} \\
\text { ratio in } \\
\text { roots }\end{array}$ \\
\hline \multirow[t]{6}{*}{$-\mathrm{M}^{\mathrm{a}}$} & \multirow[t]{3}{*}{25} & 0 & 0.86 & 1.00 & 0.19 & 1.79 & 4789 & 571 \\
\hline & & 25 & 0.92 & 1.07 & 0.31 & 2.01 & 3034 & 531 \\
\hline & & 100 & 0.93 & 1.12 & 0.18 & 2.07 & 6337 & 539 \\
\hline & \multirow[t]{3}{*}{100} & 0 & 0.88 & 1.06 & 0.32 & 2.02 & 3321 & 538 \\
\hline & & 25 & 0.89 & 1.05 & 0.36 & 1.87 & 2645 & 563 \\
\hline & & 100 & 0.91 & 1.07 & 0.30 & 2.39 & 3167 & 454 \\
\hline \multirow[t]{6}{*}{$+\mathrm{M}$} & \multirow[t]{3}{*}{25} & 0 & 1.94 & 1.90 & 0.12 & 0.72 & 18606 & 2662 \\
\hline & & 25 & 2.15 & 1.88 & 0.12 & 0.94 & 19504 & 2027 \\
\hline & & 100 & 2.35 & 1.99 & 0.09 & 1.04 & 27535 & 1980 \\
\hline & \multirow[t]{3}{*}{100} & 0 & 2.59 & 2.37 & 0.08 & 0.69 & 31242 & 3757 \\
\hline & & 25 & 2.63 & 2.58 & 0.08 & 0.86 & 35299 & 3155 \\
\hline & & 100 & 2.36 & 2.42 & 0.05 & 0.97 & 53127 & 2496 \\
\hline \multicolumn{9}{|c|}{ Significance $^{\mathrm{b}}$ of } \\
\hline \multicolumn{2}{|c|}{ Inoculation (I) } & & $* * *$ & $* * *$ & $* * *$ & $* * *$ & $* * *$ & $* * *$ \\
\hline \multicolumn{2}{|c|}{ Phosphorus (P) } & & $* * *$ & $* * *$ & NS & NS & $* *$ & $* *$ \\
\hline \multicolumn{2}{|c|}{ Arsenic (A) } & & NS & NS & $*$ & $* * *$ & NS & $*$ \\
\hline \multicolumn{2}{|l|}{$\mathrm{I} \times \mathrm{P}$} & & $* * *$ & $* * *$ & $* * *$ & NS & $* *$ & $* *$ \\
\hline \multicolumn{2}{|l|}{$\mathrm{I} \times \mathrm{A}$} & & NS & NS & NS & NS & NS & NS \\
\hline \multicolumn{2}{|l|}{$\mathrm{P} \times \mathrm{A}$} & & $*$ & NS & NS & NS & NS & NS \\
\hline \multicolumn{2}{|l|}{$\mathrm{I} \times \mathrm{P} \times \mathrm{A}$} & & $*$ & NS & NS & NS & NS & NS \\
\hline
\end{tabular}

${ }^{\mathrm{a}}-\mathrm{M}$ and $+\mathrm{M}$ represent uninoculated and inoculated treatments respectively; ${ }^{\mathrm{b}} \mathrm{By}$ analysis of variance; ${ }^{* * *}, P<0.001 ;{ }^{* *}, P<0.01 ;{ }^{*}, \mathrm{PL} 0.05 ; \mathrm{NS}$, not significant. 


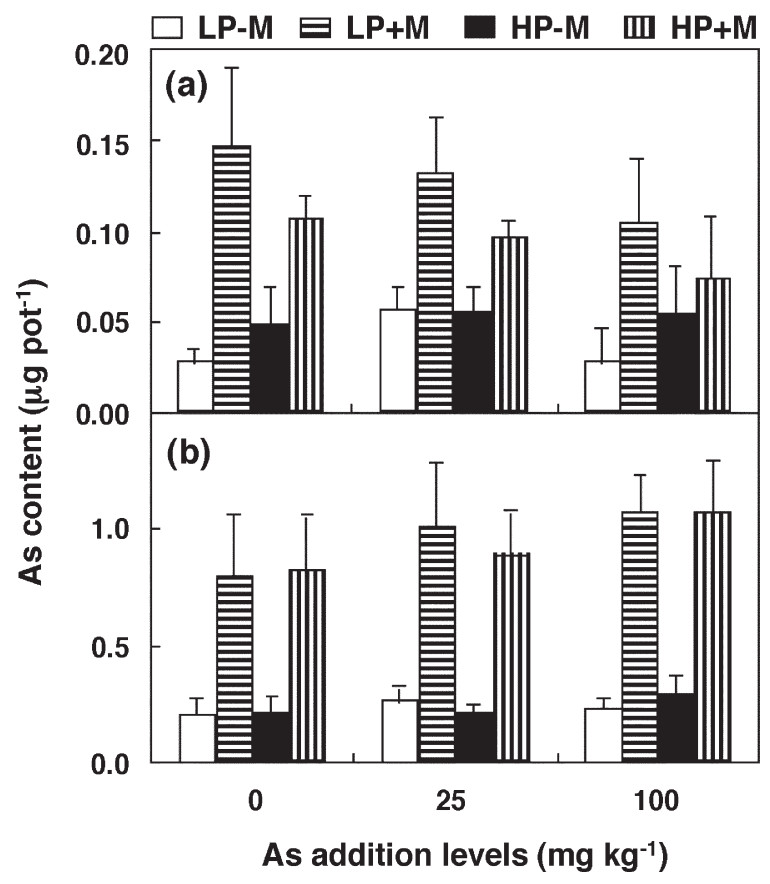

Fig. 3. As content of shoots (a) and roots (b) of M. sativa. $-\mathrm{M}$ and $+\mathrm{M}$ represent uninoculated and inoculated treatments. LP and HP refer to 25 and $100 \mathrm{mg} \mathrm{P} \mathrm{kg}^{-1}$ in $\mathrm{HCP}$ respectively.

of the two elements in soil (Johnson and Barnard, 1979; Rodriguez et al., 2003). Soil-available As and P were therefore both extracted with $0.5 \mathrm{~mol} \mathrm{~L}^{-1} \mathrm{NaHCO}_{3}(\mathrm{pH}$ 8.5; soil: water ratio, 1:20; extraction for $30 \mathrm{~min}$ ). Available As and $\mathrm{P}$ were determined as described above.

\subsection{Statistical analysis}

Data were subjected to three-way ANOVA to compare mycorrhizal status, $\mathrm{P}$ and As addition levels using GenStat for PC/Windows 6.1 (GenStat Committee, 2002).

\section{Results}

\subsection{Colonization of roots and soil by $G$. mosseae}

Roots of inoculated plants were extensively colonized by $G$. mosseae irrespective of $\mathrm{P}$ or As addition levels in side-arms, whereas roots of uninoculated plants remained uncolonized.

In inoculated treatments, hyphal length densities in RHC and HCP were mostly higher than those in HCA. At the higher $\mathrm{P}$ addition level hyphal development in HCP was higher $(P<0.001)$, while As addition showed negative effects on hyphal growth in RHC $(P<0.01)$ but not in HCA. Small amounts of hyphae (not more than
$0.2 \mathrm{~m} \mathrm{~g}^{-1}$ ) were also present in some pots with uninoculated plants (data not shown). These were probably dead or saprophytic and were assumed to be present also in the inoculated treatments.

\subsection{Plant growth}

Colonization by G. mosseae dramatically increased both shoot and root dry weight by a factor of approximately six $(P<0.001)$ (Fig. 2). Phosphorus addition in the side-arm only slightly increased shoot dry weight $(P<0.05)$, while As addition had no effect on plant growth. Colonization also increased total root length and root/shoot ratios (data not shown), and these were not affected by side-arm treatments (Table 1).

\subsection{Plant phosphorus nutrition}

Phosphorus concentrations in both plant shoots and roots were significantly increased by AMF colonization $(P<0.001)$ (Table 2). Concentrations in AM plants were generally twice those of corresponding uninoculated controls. The significant interaction of $\mathrm{P}$ addition with inoculation $(P<0.001)$ was in accordance with the fact that $\mathrm{P}$ treatment influenced inoculated plants only.

$P$ contents (total P per pot) of plant shoots and roots were also markedly increased by AMF colonization $(P<0.001)$ and those of AM plants were increased by $\mathrm{P}$ addition in HCP $(P<0.001)$. The root/shoot ratios of total $\mathrm{P}$ content showed no significant differences between treatments, and were constant at ca. 0.80 .

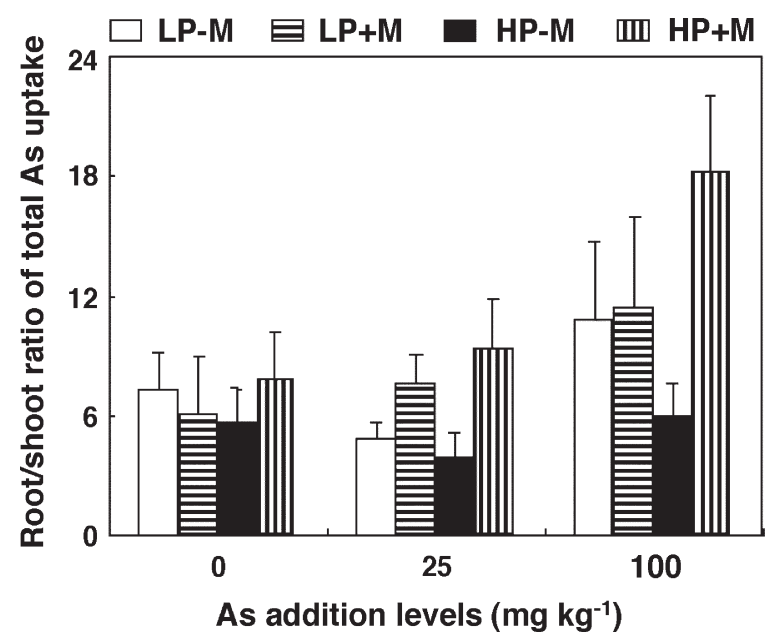

Fig. 4. Root/shoot ratios of total As uptake by $M$. sativa. $-\mathrm{M}$ and $+\mathrm{M}$ represent uninoculated and inoculated treatments. LP and HP refer to 25 and $100 \mathrm{mg} \mathrm{P} \mathrm{kg}^{-1}$ in HCP respectively. 
Table 3

Changes in soil extractable P and As in different compartments of the 'cross-pots'

\begin{tabular}{|c|c|c|c|c|c|}
\hline \multirow[t]{2}{*}{$\begin{array}{l}\text { Inoculation } \\
\text { treatment }\end{array}$} & \multirow[t]{2}{*}{$\begin{array}{l}\text { P levels } \\
\text { in } \mathrm{HCP} \\
\left(\mathrm{mg} \mathrm{kg}^{-1}\right)\end{array}$} & \multirow[t]{2}{*}{$\begin{array}{l}\text { As levels } \\
\left.\text { in } \mathrm{HCA}^{-1}\right) \\
\left(\mathrm{mg} \mathrm{kg}^{-1}\right)\end{array}$} & \multicolumn{2}{|c|}{$\begin{array}{l}\text { Extractable } \\
\text { soil P } \\
\left(\mathrm{mg} \mathrm{kg}^{-1}\right)\end{array}$} & \multirow{2}{*}{$\begin{array}{l}\text { Extractable As } \\
\left(\mathrm{mg} \mathrm{kg}^{-1}\right)\end{array}$} \\
\hline & & & $\mathrm{PC}$ & $\mathrm{HCP}$ & \\
\hline \multirow[t]{6}{*}{$-\mathrm{M}^{\mathrm{a}}$} & 25 & 0 & 6.37 & 35.45 & 0.27 \\
\hline & & 25 & 5.40 & 34.49 & 6.84 \\
\hline & & 100 & 7.43 & 32.52 & 33.22 \\
\hline & 100 & 0 & 5.60 & 68.97 & 0.23 \\
\hline & & 25 & 5.57 & 66.75 & 6.03 \\
\hline & & 100 & 7.10 & 63.43 & 34.75 \\
\hline \multirow[t]{6}{*}{$+\mathrm{M}$} & 25 & 0 & 4.23 & 14.93 & 0.22 \\
\hline & & 25 & 3.58 & 14.89 & 5.68 \\
\hline & & 100 & 3.40 & 14.52 & 29.75 \\
\hline & 100 & 0 & 3.82 & 53.98 & 0.24 \\
\hline & & 25 & 4.22 & 54.20 & 6.61 \\
\hline & & 100 & 4.56 & 46.68 & 33.07 \\
\hline \multicolumn{6}{|c|}{ Significance $^{\mathrm{b}}$ of } \\
\hline \multicolumn{2}{|c|}{ Inoculation (I) } & & $* * *$ & $* * *$ & NS \\
\hline \multicolumn{2}{|c|}{ Phosphorus (P) } & & NS & $* * *$ & NS \\
\hline \multicolumn{2}{|c|}{ Arsenic (A) } & & NS & $*$ & $* * *$ \\
\hline \multicolumn{2}{|l|}{$\mathrm{I} \times \mathrm{P}$} & & NS & NS & NS \\
\hline \multicolumn{2}{|l|}{$\mathrm{I} \times \mathrm{A}$} & & NS & NS & NS \\
\hline \multicolumn{2}{|l|}{$\mathrm{P} \times \mathrm{A}$} & & NS & NS & NS \\
\hline \multicolumn{2}{|l|}{$\mathrm{I} \times \mathrm{P} \times \mathrm{A}$} & & NS & NS & NS \\
\hline
\end{tabular}

$\overline{\mathrm{a}_{-} \mathrm{M} \text { and }+\mathrm{M} \text { represent uninoculated and inoculated treatments }}$ respectively;

${ }^{\mathrm{b}}$ By analysis of variance; ***, $P<0.001 ; *, P<0.05$; NS, not significant.

\subsection{Arsenic uptake and partitioning}

In general, AMF colonization significantly decreased As concentrations in both plant shoots and roots $(P<0.001)$ (Table 2). Root As concentrations increased slightly with increasing As levels in HCA $(P<0.01)$. Interactions of inoculation with $\mathrm{P}$ addition were significant $(P<0.001)$ : the higher $\mathrm{P}$ addition level (100 mg P kg-1) led to significantly higher shoot As concentrations for uninoculated plants, but lower shoot As concentrations for AM plants.

Both shoot and root As contents were markedly increased by colonization $(P<0.001)$ (Fig. 3), partly (but by no means entirely) reflecting increased plant biomass (Fig. 1). Increasing As addition levels in HCA increased root As contents $(P<0.05)$, especially for AM plants, but slightly decreased shoot As contents $(P=0.055)$. There were significant interactions of inoculation with $\mathrm{P}$ addition $(P<0.05)$ : higher $\mathrm{P}$ addition level in HCP resulted in lower shoot As concentrations for AM plants, but showed no significant influences on uninoculated controls.
Root/shoot ratios of total As uptake were increased both by colonization $(P<0.01)$ and by increasing As addition levels in HCA $(P<0.01)$ (Fig. 4). Compared with addition of $25 \mathrm{mg} \mathrm{P} \mathrm{kg}-1$ in $\mathrm{HCP}$, addition of $100 \mathrm{mg} \mathrm{P} \mathrm{kg}{ }^{-1}$ resulted in lower root/shoot ratios of total As uptake for uninoculated plants but higher ratios for AM plants.

\section{5. $P /$ As ratio in plants}

The $\mathrm{P} / \mathrm{As}$ ratios in shoots were much higher than those in roots (Table 2). Furthermore, AMF colonization markedly increased the $\mathrm{P} / \mathrm{As}$ ratios both in shoots and in roots $(P<0.001)$. For AM plants, the higher $\mathrm{P}$ addition level in HCP also resulted in higher $\mathrm{P} / \mathrm{As}$ ratios in both shoots and roots, while for uninoculated controls, higher $\mathrm{P}$ level decreased $\mathrm{P} / \mathrm{As}$ ratios in shoots (significant interaction of inoculation with $\mathrm{P}$ addition, $P<0.01)$. $\mathrm{P} /$ As ratios in roots decreased with increasing As addition levels in HCA $(P<0.05)$, and this was more obvious for AM treatments.

\subsection{Soil P and As depletion}

There was more $\mathrm{P}$ depletion from RHC by mycorrhizal roots and hyphae than in uninoculated treatments, and lower values for $\mathrm{P}$ in $\mathrm{HC}$ with inoculated treatments also reflect uptake by hyphae $(P<0.001)$ (Table 3). Depletion of P from HCA was not measured. Extractable P in HCP remained higher in treatments with $\mathrm{P}$ addition, especially in uninoculated treatments for which $\mathrm{P}$ in $\mathrm{HCP}$ was inaccessible $(P<0.001)$. Extractable $\mathrm{P}$ in HCP decreased slightly with increasing As addition levels in HCA $(P<0.05)$. Extractable As in HCA remained high in treatments with additional As $(P<0.001)$, but was not affected by mycorrhiza and $\mathrm{P}$ treatments (Table 3 ).

\section{Discussion}

Results presented here provide insights into the mechanisms of AMF-mediated plant uptake of As in relation to $\mathrm{P}$ supply. Because $\mathrm{P}$ and As were added only to the side-arms, these two treatments did not influence plant growth significantly. This experimental system thus allowed direct comparison of the effects of AMF on uptake of As and $\mathrm{P}$ via different hyphae into the same individual plants, and those inoculated plants were all matched well in size. It was therefore possible to examine hyphal uptake of As and $\mathrm{P}$ and their potential interactions in ways that could be distinguished from AM-mediated increases in plant growth. 
In this cultivation system, AM dramatically increased plant $\mathrm{P}$ uptake, and inoculated plants contained 15-20 fold more $\mathrm{P}$ than the uninoculated controls. Likewise, AM plants also took up much more As than uninoculated ones, both in the absence and presence of As in HCA. The extra As uptake is probably not just contributed by the AMF in RHC and $\mathrm{HC}$, as it may include As uptake by the much larger roots in RHC. Conversely, if formation of AM resulted in complete inactivation of high-affinity plant P transporters (Smith et al., 2004), it is possible that AM plants might have taken up all the $\mathrm{P}$ and As via the AMF.

Arsenate is a phosphate analogue and is transported across the plasma membrane of root cells via highaffinity phosphate transporters (Meharg and Macnair, 1990, 1991, 1992). In non-arsenate tolerant H. lanatus, the uptake of both phosphate and arsenate was much greater than for tolerant plants at low phosphate and arsenate concentrations, while high-affinity uptake appeared to be absent in the tolerant genotypes for both anions (Meharg and Macnair, 1990). Wright et al. (2000) hypothesized that AM colonization could play a major part in the maintenance of higher shoot $\mathrm{P}$ concentration and thus the suppression of phosphate uptake in arsenate-tolerant $H$. lanatus, which subsequently operates the SPU polymorphism by means of homeostatic feedback mechanism. On the other hand, Smith et al. $(2003$; 2004) recently demonstrated that AM colonization and $\mathrm{P}$ uptake via the mycorrhizal pathway can result in complete inactivation of the direct $\mathrm{P}$ uptake pathway via root hairs and epidermis. Therefore, AMF could most likely decrease arsenate uptake into roots by suppressing the high-affinity arsenate/phosphate transporters. We did not evaluate the influences of AM colonization on As uptake via the root pathway or the mycorrhizal pathway and the selectivity between highaffinity transporters for arsenate and phosphate needs further study. However, there is no doubt that the improved $\mathrm{P}$ nutrition and growth of AM plants considerably "diluted" As in both shoots and roots, due to relatively small hyphal uptake of As compared with P. This "dilution effect" led to extremely high $\mathrm{P} / \mathrm{As}$ ratios (Table 2) in plant tissues. The much higher $\mathrm{P} / \mathrm{As}$ ratios in $\mathrm{AM}$ plants clearly show that AM colonization is likely to help host plants exclude As from potentially toxic soils.

High P in HCP slightly decreased shoot As contents in AM plants, and this can be explained by $\mathrm{P}$ effects on As translocation from roots to shoots. This has to be interpreted as a mycorrhizal effect on As partitioning, as added P in HCP could only influence plants via hyphal function. Clearly, AM plants partitioned less As to shoots compared with uninoculated controls. This may be due to lower xylem loading of As resulting from higher $\mathrm{P}$ concentrations and lower As concentrations in AM roots (Table 2), and could potentially alleviate As toxicity in AM plants in general. When the two HCs have $25 \mathrm{mg} \mathrm{P} \mathrm{kg}^{-1}$ (in $\mathrm{HCP}$ ) and $25 \mathrm{mg} \mathrm{As} \mathrm{kg}^{-1}$ (in HCA), the root $\mathrm{P} / \mathrm{As}$ ratio is 2027 and the shoot $\mathrm{P} / \mathrm{As}$ ratio is 19504; while with $100 \mathrm{mg} \mathrm{P} \mathrm{kg}{ }^{-1}$ and $100 \mathrm{mg}$ As $\mathrm{kg}^{-1}$ the root $\mathrm{P} / \mathrm{As}$ ratio is 2496 and the shoot $\mathrm{P} / \mathrm{As}$ ratio is 53127 (Table 2). This furthermore demonstrates that increasing both As and P by the same amounts in the separate $\mathrm{HCs}$ resulted in relatively more $\mathrm{P}$ uptake than As by the hyphae (from the HCs), and more P transfer to the shoot.

The greater depletion of P in both RHC and HCP by AM plants (Table 3 ) is as expected by rapid $\mathrm{P}$ uptake through the mycorrhizal pathway. In contrast, uptake of As by AM hyphae from HCA was so small that differences between AM and uninoculated plants were not detectable by chemical analysis. Differences in depletion showed that hyphae took up more P from HCP with the highest level of As in HCA. This seems to reflect systemic effects throughout the fungal mycelium on uptake caused by higher $\mathrm{P}$ or As concentrations in hyphae. However, this requires further investigation. The current experimental design could not provide further information in $\mathrm{P}-\mathrm{As}$ interactions in $\mathrm{AM}$ plants because $\mathrm{P}$ and As were added to different hyphal compartments to avoid direct competitive interactions between the two elements at the same membrane transport sites in roots or extraradical hyphae.

It has recently been proposed that mycorrhizal fungi, which are near-ubiquitous in soil, should be considered in phytoremediation of soils contaminated by metal(loid) s (Khan et al., 2000; Leyval et al., 2002), and that AMF could potentially be used to assist phytostabilization of metals in contaminated environments (Leyval et al., 2002; Chen et al., 2005). From the present study it is not clear whether AMF function like ericoid mycorrhizal fungi that can protect their host plant against As contamination by reducing arsenate to arsenite and pumping out the latter (Sharples et al., 1999, 2000a,b). Knudson et al. (2003) reported that AMF neither conferred As tolerance in basin wild-rye (Leymus cinereus [Scribner and Merr.] A. Love), nor influenced biomass production. It is also not clear from that study whether the "dilution" mechanism could still function when AMF do not produce positive growth responses, i.e. whether hyphal uptake always dominates uptake of $\mathrm{P}$ and As and is more selective against As than direct uptake via roots.

In conclusion, this study provides further evidence for the protective effects of AMF on host plants against As contamination, and has uncovered key aspects of 
underlying mechanisms that AMF can stimulate plant growth by improving P nutrition, thus produce "dilution effects" on tissue As, and reduce As partitioning to shoots. However, it is not yet clear if AMF could be employed to minimize As accumulation in crop plants grown in soils with low or moderate As contaminations (especially where the plants are not responsive to AMF), or applied for phytostabilization of As in contaminated sites. It might be possible to use AMF for As phytoextraction to clean up contaminated soils using As hyperaccumulators such as Pteris vittata (Liu et al., 2005). Considering the possible differences in AMF response to As in a spiked soil and polluted soil from the field, more work needs to be done with AMF isolates that originate from As-contaminated environments, to reveal the possible application of AMF in the management of As contaminated soils. Given the fact that there is little information available on the potential role of AMF in plant accumulation of As and mechanisms involved, further studies using radioactive tracers and molecular techniques are warranted.

\section{Acknowledgements}

This work was financially supported by the Natural Science Foundation of China (Project 40321011 and 40401031).

\section{References}

Chen BD, Roos P, Borggaard OK, Zhu Y-G, Jakobsen I. Mycorrhiza and root hairs in barley enhance acquisition of phosphorus and uranium from phosphate rock but mycorrhiza decreases root to shoot uranium transfer. New Phytol 2005;165:591-8.

GenStat Committee. The guide to GenStat (release 6.1). Part 1: Syntax and data management. Payne RW, Hemel Hempstead, UK: VSN International; 2002.

Giovannetti M, Mosse B. An evaluation of techniques for measuring vesicular arbuscular mycorrhizal infection in roots. New Phytol 1980;84:489-500.

Gonzalez-Chavez C, Harris PJ, Dodd J, Meharg AA. Arbuscular mycorrhizal fungi confer enhanced arsenate resistance on Holcus lanatus. New Phytol 2002;155:163-71.

Hanson WC. The photometric determination of phosphorus in fertilisers using the phosphovanado-molybdate complex. J Sci Food Agric 1950;1:172-3.

Jakobsen I, Abbott LK, Robson AD. External hyphae of vesiculararbuscular mycorrhizal fungi associated with Trifolium subterranum L. (1) Spread of hyphae and phosphorus inflow into roots. New Phytol 1992;120:371-80.

Johnson SE, Barnard WM. Comparative effectiveness of fourteen solutions for extracting arsenic from four western New York soils. Soil Sci Soc Am J 1979;43:304-8.

Khan AG, Kuek C, Chaudhry TM, Khoo CS, Hayes WJ. Role of plants, mycorrhizae and phytochelators in heavy metal contaminated land remediation. Chemosphere 2000;41:197-207.
Knudson JA, Meikle T, Deluca TH. Role of mycorrhizal fungi and phosphorus in the arsenic tolerance of basin wildrye. J Environ Qual 2003;32:2001-6.

Leyval C, Joner EJ, del Val C, Haselwandter K. Potential of arbuscular mycorrhizal fungi for bioremediation. In: Gianinazzi S, Schüepp H, Barea JM, Haselwandter K, editors. Mycorrhizal technology in agriculture. Basel, Switzerland: Birkhäuser Verlag; 2002.

Liu Y, Zhu Y-G, Chen BD, Christie P, Li XL. Influence of the arbuscular mycorrhizal fungus Glomus mosseae on uptake of arsenate by the As hyperaccumulator fern Pteris vittata L. Mycorrhiza 2005;15:187-92.

Meharg AA, Hartley-Whitaker J. Arsenic uptake and metabolism in arsenic resistant and nonresistant plant species. New Phytol 2002;154:29-43.

Meharg AA, Macnair MR. An altered phosphate uptake system in arsenate-tolerant Holcus lanatus L. New Phytol 1990;116: 29-35.

Meharg AA, Macnair MR. The mechanisms of arsenate tolerance in Deschampsia cespitosa (L.) Beauv and Agrostis capillaris L. New Phytol 1991;119:291-7.

Meharg AA, Macnair MR. Suppression of the high-affinity phosphateuptake system - a mechanism of arsenate tolerance in Holcus lanatus L. J Exp Bot 1992;43:519-24.

Murphy EA, Aucott M. An assessment of the amounts of arsenical pesticides used historically in a geographical area. Sci Total Environ 1998;218:89-101.

Nriagu JO. Arsenic in the environment: part 1 cycling and characterization, vol. 430. New York, USA: Wiley; 1994.

Olsen SR, Cole CV, Watanabe FS, Dean LA. Estimation of available phosphorus in soils by extraction with sodium bicarbonate. USDA Circ 1954;939:1-19.

Pearson JN, Jakobsen I. The relative contribution of hyphae and roots to phosphorus uptake by arbuscular mycorrhizal plants measured by dual labelling with ${ }^{32} \mathrm{P}$ and ${ }^{33} \mathrm{P}$. New Phytol 1993;124: 489-94.

Phillips JM, Hayman DS. Improved procedures for clearing and staining parasitic and vesicular-arbuscular mycorrhizal fungi for rapid assessment of infection. Trans Br Mycol Soc 1970;55:158-61.

Rodriguez RR, Basta NT, Casteel SW, Armstrong FP, Ward DC. Chemical extraction methods to assess bioavailable arsenic in soil and solid media. J Environ Qual 2003;32:876-84.

Rosen BP. Families of arsenic transporters. Trends Microbiol 1999;7: 207-12.

Sharples JM, Meharg AA, Chambers SM, Cairney JWG. Arsenate sensitivity in ericoid and ectomycorrhizal fungi. Environ Toxicol Chem 1999;18:848-1855.

Sharples JM, Meharg AA, Chambers SM, Cairney JWG. Mechanism of arsenate resistance in the ericoid mycorrhizal fungus Hymenoscyphus ericae. Plant Physiol 2000a;124:1327-34.

Sharples JM, Meharg AA, Chambers SM, Cairney JWG. Symbiotic solution to arsenic contamination. Nature 2000b;404:951-2.

Smith SE, Read DJ. Mycorrhizal symbiosis. 2nd edition. London, UK: Academic Press; 1997.

Smith SE, Smith FA, Jakobsen I. Mycorrhizal fungi can dominate phosphate supply to plants irrespective of growth responses. Plant Physiol 2003;133:6-20.

Smith SE, Smith FA, Jakobsen I. Functional diversity in arbuscular mycorrhizal (AM) symbioses: the contribution of the mycorrhizal $\mathrm{P}$ uptake pathway is not correlated with mycorrhizal responses in growth or total P uptake. New Phytol 2004;162:511-24.

Tennant D. A test of a modified line intersect method of estimating root length. J Ecol 1975;63:995-1001. 
Vilanó M, Rubio R. Determination of arsenic in seafood by focused microwave digestion and hydride generation-atomic fluorescence detection. J AOAC Int 2001;84:551-5.

Wright W, Fitter A, Meharg A. Reproductive biomass in Holcus lanatus clones that differ in their phosphate uptake kinetics and mycorrhizal colonization. New Phytol 2000;146: 493-501.

Woolson EA, Axley JH, Kearney PC. The chemistry and phytotoxicity of arsenic in soils. I. Contaminated field soils. Soil Sci Soc Am Proc 1971;35:938-43. 